\title{
The growing importance of Enterococcus and Streptococcus agalactiae in uncomplicated urinary tract infections
}

KATARZYNA JERMAKOW'1, 2, A-G, MAGDALENA PAJACZZKOWSKA, в, c,

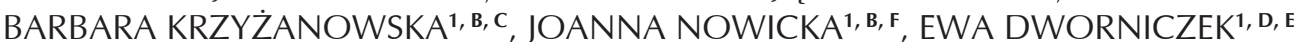

${ }^{1}$ Department of Microbiology, Medical University of Wroclaw

${ }^{2}$ Specialist Microbiological Laboratory of the Medical University Foundation microFAM in Wroclaw

A - Study Design, B - Data Collection, C - Statistical Analysis, D - Data Interpretation, E - Manuscript Preparation, F - Literature Search, G - Funds Collection

Summary Background. Urinary tract infections (UTIs) represent $10-20 \%$ of all community-acquired infections. Escherichia coli remains the most commonly isolated microorganism. Because of the dominance of these bacteria, routine laboratory tests are not recommended in making the first UTI diagnosis. However, careful monitoring of all etiological agents of uncomplicated UTIs should be an important strategy for empirical therapy.

Objectives. A determination of the incidence of UTI bacterial etiological agents in outpatients.

Material and methods. The results of urine cultures were analyzed. The samples were obtained in the period from 01.2011 to 03.2013 from outpatients of all age groups.

Results. The rods of Escherichia coli were the most frequently identified microorganisms responsible for uncomplicated UTIs. They were isolated from $52 \%$ of infected patients. Every fourth case of UTI indicated the participation of Enterococcus spp. and Streptococcus agalactiae. The next $21 \%$ of infections were caused by Gram-negative bacteria other than $E$. coli. The role of coagulase-negative staphylococci was insignificant and equaled less than $2 \%$.

Conclusions. Despite the dominant role of $E$. coli in urinary tract infections, there has been a decrease in the frequency of its isolation. However, the natural resistance of Enterococcus spp. to antibiotics increases the number of urinary tract infections caused by these bacteria. Streptococcus agalactiae is a UTI cause with similar frequency in women of reproductive age and postmenopausal women. Monitoring of the incidence of uncomplicated infections facilitates empirical treatment and prevents UTI recurrence.

Key words: Streptococcus agalactiae, Enterococcus spp., uncomplicated urinary tract infection.

Fam Med Prim Care Rev 2016; 18(3): 250-252

\section{Background}

Urinary tract infections (UTIs) comprise about 10-20\% of all community-acquired infections. Women are the dominant group of patients. This is related to anatomical structure and the ease with which bacteria colonize the urogenital organs, mainly from the area of the gastrointestinal tract. Other factors that increase the risk of urinary tract infections include: sexual contact, the use of contraceptive spermicides, and residual urine in the bladder. According to statistics, bacteriuria occurs at least once in the lifetime of approximately $10 \%$ of the female population. Estimates indicate that about half of women and one in ten men experience urinary tract infection in their lives $[1,4]$. The Polish Recommendations for the Diagnosis, Therapy and Prevention of urinary tract infections [1] indicate that laboratory tests, including tests of urine sediment and culture, are not necessary in making a diagnosis of the first UTI episode. Stating the first UTI episode in a person without the risk of complications allows for making the UTI diagnosis, already based on the clinical symptoms. However, because these infections are the second most common reason for reporting to a doctor, after respiratory tract infections, periodic verification of the knowledge about UTI causes seems to be justified. Our own laboratory observations conducted in patients in a given region, in this case in Lower Silesia, are extremely important.

\section{Objectives}

A determination of the incidence of various urinary tract infection pathogens in outpatients on the basis of the analysis of microbiological urine results.

\section{Material and methods}

The urine culture results were analyzed in dysuric outpatients with symptoms of varying severity over 26 months (from 01.2011 to 03.2013). The most common UTI symptoms reported by patients were: urinary frequency, pain during urination, abdominal pain, pain in the lower abdomen and/or lumbar region, changed color and/or odor of urine. Less frequently patients reported fever, weakness and decreased appetite. All subjects provided urine for culture to the Specialist Microbiological Laboratory of the Medical University Foundation microFAM in Wroclaw. The tests were performed by a quantitative method (calibrated loops) on Columbia Agar medium with 5\% sheep blood, MacConkey Agar and Sabouraud Agar (Becton Dickinson). The identification of pathogens was performed in an automatic BBL Crystal system (Becton Dickinson) based on the biochemical activity of microorganisms in accordance with the recommendations of the National Consultant for Clinical Microbi- 
ology. 753 urine cultures were analyzed. The examinations were performed on the order of a physician, but also at the patient's request.

\section{Results}

Out of $753(100 \%)$ urine cultures the result was normal in $64 \%$, i.e. the number of bacteria in urine was not higher than $1000 \mathrm{CFU} / \mathrm{ml}$ (CFU - colony-forming unit). Mixed bacterial flora were grown from one tenth of the samples (9\%). Since none of the contaminated samples came from a catheterized patient, the presence of various microbial species proved an improper technique of urine collection and/or transport. The comparison of age groups showed that the most contaminated urine samples were provided by people aged between 61 and 85 years.

Escherichia coli (Enterobacteriaceae family) is the most frequently isolated pathogen in uncomplicated UTIs. In our study, which included 206 positive urine cultures, Escherichia coli was isolated 107 times $(52 \%)$, with a frequency independent of age.

Enterococci and streptococci are the second most common (25\%) microorganisms responsible for UTIs, especially Enterococcus faecalis - 13\%, Enterococcus faecium - 1\% and $\beta$-hemolytic Streptococcus group B, Streptococcus agalactiae $(11 \%)$. Most patients with uncomplicated UTIs caused by enterococci were over 50 years (68\%). Streptococci, including Streptococcus agalactiae, were isolated more often in women $(87 \%)$ than in men $(3 \%)$. More than half were people of childbearing age (between 20 and 40 years), and $40 \%$ were over 61 years.

Gram-negative rods other than Escherichia coli were isolated with a frequency of $21 \%$ (Klebsiella spp., Proteus spp., Pseudomonas spp., Enterobacter spp., and Serratia spp. the order is consistent with the frequency of isolation dominated). The group of coagulase-negative staphylococci was the cause of only 3 out of 206 confirmed UTI cases, which accounted for less than $2 \%$ of all positive urine cultures. $\mathrm{Co}$ rynebacterium urealiticum was identified (at a quantity of $100000 \mathrm{CFU} / \mathrm{ml}$ ) in one patient (a 92-year-old male). None of the cultures demonstrated yeast in significant amounts.

\section{Discussion}

The results indicate that almost every tenth outpatient does not have adequate knowledge about the proper collection and transport of urine for microbiological tests. This is a mistake which delays antibiotic therapy and generates high costs of tests, although it can be effectively prevented. Sometimes, it is appropriate for medical personnel to repeatedly instruct the patient. If the urine is contaminated, i.e. many species of microorganisms are isolated from one sample and clinical UTI symptoms persist, re-examination should be ordered. We ought to remember to clearly instruct the patient as to the correct method of collection and transport of the material. Instructions on the necessity of midstream urine collection and hygiene in the area surrounding the urethra before voiding are crucial. Microbes colonizing the final section of the urethra belong to the same species as the most common pathogens of uncomplicated UTIs.

According to our study, Escherichia coli was responsible for $52 \%$ of UTI cases. Slightly higher results were obtained by the Microbiological Laboratory of the Institute of Mother and Child in Warsaw [4] and the Laboratory of Clinical Microbiology, University Clinical Center of Gdańsk [5], which reported the frequency of $E$. coli isolation from urine at 54 and $62 \%$, respectively. Meanwhile, according to the literature data $[1,3,6,7]$, the frequency with which
E. coli is identified in uncomplicated urinary tract infections is $75-95 \%$. Thus, in some Polish centers we observe a decrease in the frequency of isolation of these bacteria from UTI cases. This may be a sign of rising drug resistance to first choice therapy drugs, often used in empirical therapy of outpatients. It seems, however, that the dominant position of $E$. coli in urinary tract infections is unthreatened.

Enterococcus faecalis are responsible for $7-10 \%$ of urinary tract infections, and are often identified in patients with anatomical abnormalities of the urinary tract, or after urological procedures $[1,5,7]$. Our study has shown a higher, $14 \%$ share of Enterococcus in UTIs. The test results obtained in the Gdańsk center [5] indicate that enterococci are the cause of $20 \%$ of urinary tract infections, making them the second UTI etiological factor after Escherichia coli. The reason for this phenomenon can be very complex. The introduction to outpatient therapy of oral cephalosporins with high activity against enterobacteria, such as Escherichia coli, Proteus mirabilis, and Klebsiella pneumoniae, selects enterococci inherently resistant to this class of drugs. The use of cephalosporins in the treatment destroys a part of the intestinal microflora, especially Enterobacteriaceae, and causes the selection and multiplication of resistant strains. The reconstruction of intestinal microbiota after antibiotic treatment is a long process that takes up to 8 weeks. At this time, enterococci may obtain numerical superiority in the gastrointestinal tract and thereby cause a growing number of infections, including urinary tract infections. In addition to cephalosporins, the overuse of clindamycin, aminoglycosides and co-trimoxazole [6], for which the bacteria have natural resistance, may be the selecting agent for enterococci. It is worth noting that in the case of Enterococcus the growing number of infections and therapeutic problems are not connected with increasing resistance in this group of microorganisms, but with their natural resistance to the drugs, which are also used beyond the outpatient treatment. The improper selection of antibiotics in empiric therapy (diagnosis of the first UTI episode does not require laboratory tests, including culture) leads to treatment failure and UTI recurrence (re-infection) caused by micro-organisms, including Enterococcus spp. It should be noted that the Recommendations for the Diagnosis, Therapy and Prevention of urinary tract infections [1] indicate the need for relapse treatment based on urine culture and antibiogram results.

The CDC group dedicated to the prevention of perinatal infection (Perinatal Group B Streptococcal Disease) recommends reporting positive cultures of Streptococcus agalactiae (GBS) in pregnant women $(10000 \mathrm{CFU} / \mathrm{ml}$ of urine in monoculture or as a second pathogen) [1]. The Polish recommendations indicate that $S$. agalactiae can cause UTIs in both pregnant and non-pregnant women, especially those with diabetes. Thus, taking into account the limited availability of laboratory information on the state of the patient's health (pregnancy, diabetes, etc.), it seems reasonable to report the presence of GBS in the amount of $10000 \mathrm{CFU} /$ $/ \mathrm{ml}$ in the urine of all patients, leaving the decision to undertake treatment to the doctor. In the analyzed results of urine culture, streptococcus S. agalactiae was isolated in 14\% of cases. These bacteria are identified in significant numbers mainly in women (87\%), and this is associated with vaginal carriage, which in healthy women reaches $50-75 \%$ [6]. S. agalactiae caused UTIs not only in young women of childbearing age. The analysis of age groups showed that 10 women were in the age group 20-40 years, whereas 9 subjects were aged 61-87 years. One case of infection caused by GBS concerned a 6-year-old girl diagnosed with significant bacteriuria (1 $000000 \mathrm{CFU} / \mathrm{ml})$. Similarly, S. agalactiae was isolated in a significant quantity in urine taken from 3 males aged 22-29 years. 
The analysis of study material showed that Candida yeast was not isolated from the urine of subjects, and this is consistent with literature data and the Polish recommendations, which emphasize that patients subjected to immunosuppressive treatment are an important risk group of fungal UTIs $[1,4,6]$. Although risk factors of candiduria include diabetes, cancer, old age and the periodic use of antibiotics with a broad spectrum of action, we found no candiduria in our study group, though in the pool of 753, people older than 65 years accounted for $34 \%$ of subjects.

The role of Staphylococcus saprophyticus is often emphasized in urinary tract infections in women of reproductive age (20\% of UTIs) [1, 3, 5, 7]. Meanwhile, for years we have observed in our laboratory very low frequency of coagulase-negative staphylococci isolation in UTIs. In the analyzed period of 26 months, S. saprophyticus was isolated from less than $2 \%$ of cases. Similar results were demonstrated by Grzesik [4], who found the S. saprophyticus etiology of UTIs in 5 out of 313 positive cultures $(<2 \%)$ obtained from children. The study conducted by Bronka et al. [5] showed no single Staphylococcus among 947 positive urine cultures. Repeatedly cited sexually active women were recognized to be a risk group of staphylococcus coagulase- negative infections $[I, 3,5]$; in our group, 48 patients $(23 \%)$ were aged 16-60 years. Meanwhile, urinary tract infections with staphylococcus coagulase-negative were confirmed in 3 patients aged 47, 67 and 79 years. The quoted findings indicate the need for reviewing and updating statistical data widely cited in the literature.

\section{Conclusions}

1. There has been a decrease in the frequency of Escherichia coli isolation in uncomplicated urinary tract infections. Nevertheless, this bacterium is the dominant etiological UTI factor. The increasing incidence of urinary tract infections caused by Enterococcus spp. is due to their natural resistance to some of the frequently used antibiotics.

2. Empirical treatment of uncomplicated UTIs can contribute to the recurrence of the infection, especially if the treatment mainly covers the enterobacteria spectrum.

3. It is necessary to continuously monitor test results of urine culture in outpatients in order to verify the list of the main etiological UTI factors.

Source of funding: This work was funded by the authors' resources. Conflict of interest: The authors declare no conflict of interests.

\section{References}

1. Hryniewicz W, Holecki M. Rekomendacje diagnostyki terapii i profilaktyki zakażeń układu moczowego u dorosłych. Narodowy Program Ochrony Antybiotyków na lata 2011-2015. Warszawa: Narodowy Instytut Leków; 2015.

2. Wojtaszek E, Głogowski T. Patogeneza zakażeń układu moczowego. Terapia 2014; XXII, 12, 1(314): 34-36.

3. Kurpas D, Kiliś-Pstrusińska K. Nawracające zakażenia układu moczowego w praktyce lekarza rodzinnego - zasady diagnostyki i terapii. Terapia 2012; XX, 3, 1(269): 67-72.

4. Grzesik A, Poletyło A, Wolska A. Czynniki etiologiczne zakażeń układu moczowego u dzieci leczonych w Instytucie Matki i Dziecka. Med Wieku Rozw 2008; 12(3): 789-794.

5. Bronk M, Kochowska-Bronk M, Śledzińska A, et al. Bakterie z rodzaju Enterococcus jako ważny czynnik etiologiczny zakażeń układu moczowego u pacjentów ambulatoryjnych. Forum Med Rodz 2010; 4(3): 14-19.

6. Dzierżanowska D. Antybiotykoterapia praktyczna. Bielsko-Biała: Wydawnictwo Medyczne $\alpha$-medica press; 2000.

7. Roland A. The etiology of urinary tract infection: traditional and emerging pathogens. Am J Med 2002; 113(1A): 14-19.

Address for correspondence:

Katarzyna Jermakow, MD, PhD

Katedra i Zakład Mikrobiologii UM

ul. Chałubińskiego 4

50-368 Wrocław

Polska

Tel.: +48 71 784-12-92

E-mail: katarzyna.jermakow@umed.wroc.pl

Received: 25.04.2016

Revised: 01.05.2016

Accepted: 14.05.2016 